\title{
Faktor-Faktor yang Mempengaruhi Terjadinya Perdarahan Pasca Persalinan di RSUD Kota Prabumulih Tahun 2019
}

\author{
Gustika Anggriani \\ Akademi Kebidanan Rangga Husada Prabumulih
}

Informasi Artikel :

Diterima : 20 November 2020

Direvisi : 23 Novembe 2020

Disetujui : 03 Desember 2020

*Korespondensi Penulis :

gustika.ranggahusada@gmail.com

\section{A B S T R A K}

Perdarahan pasca persalinan yaitu adalah perdarahan atau hilangnya darah sebanyak lebih dari $500 \mathrm{ml}$ yang terjadi setelah anak lahir baik sebelum, selama, atau sesudah kelahiran plasenta. Tujuan penelitian untuk mengetahui faktor-faktor yang mempengaruhi terjadinya perdarahan pasca persalinan di Rumah Sakit Umum Daerah Tahun 2019. Penelitian ini digunakan metode survey analitik dan pendekatan Cross Sectional. Penelitian bersifat analitik, dengan mengunakan pendekatan Cross Sectional. Populasi penelitian ini adalah seluruh ibu bersalin di ruang kebidanan Rumah Sakit Umum Daerah Kota Prabumulih dari tanggal 1 Januari sampai dengan 31 Desember 2019 yaitu sebanyak 1712 orang. Sampel penelitian adalah sebagian dari populasi yaitu 324 orang. Instrumen penelitian berupa kuesioner. Analisa yang digunakan adalah analisa univariat dan bivariat. Dari analisa bivariat diketahui bahwa dari 14 responden yang mengalami partus lama terdapat 11 responden $(3,4 \%)$ didiagnosa perdarahan pasca persalinan sedangkan dari 310 responden yang tidak mengalami partus lama terdapat 76 responden $(23,5 \%)$ didiagnosa perdarahan pasca persalinan, dari 27 responden yang memiliki janin dengan makrosomia terdapat 19 responden $(5,9 \%)$ yang didiagnosa perdarahan pasca persalinan sedangkan dari 297 responden yang tidak memiliki janin dengan makrosomia terdapat 68 responden (21\%) yang didiagnosa perdarahan pasca persalinan, dari 19 responden yang mengalami anemia terdapat 15 responden $(4,7 \%)$ yang didiagnosa perdarahan pasca persalinan sedangkan dari 305 responden yang tidak mengalami anemia terdapat 72 responden $(22,2 \%)$ yang didiagnosa perdarahan pasca persalinan. Kesimpulan dari penelitian ini ada hubungan yang bermakna antara partus, makrosomia dan anemia dengan kejadian perdarahan pasca persalinan.

Kata Kunci : Perdarahan pasca persalinan, partus lama, makrosomia, anemia

\section{ABSTRACT}

Postpartum hemorrhage, namely bleeding or loss of blood of more than $500 \mathrm{ml}$ that occurs after the child is born either before, during, or after the delivery of the placenta. The research objective was to determine the factors that influence the occurrence of postpartum hemorrhage at the Regional General Hospital in 2019. This study used an analytical survey method and a Cross Sectional approach. This research is analytical, using a cross sectional approach. The population of this study were all women giving birth in the midwifery room of the Prabumulih Regional General Hospital from January 1 to December 31, 2019, namely 1712 people. The research sample was part of the population, namely 324 people. The research instrument was a questionnaire. The analysis used was univariate and bivariate analysis. From the bivariate analysis it is known that of the 14 respondents who experienced prolonged labor, 11 respondents (3.4\%) were diagnosed with postpartum hemorrhage, while of the 310 
respondents who did not experience prolonged labor, 76 respondents (23.5\%) were diagnosed with postpartum bleeding, out of 27 There were 19 respondents (5.9\%) who had a fetus with macrosomia who were diagnosed with postpartum hemorrhage, while from 297 respondents who did not have a fetus with macrosomia there were 68 respondents $(21 \%)$ who were diagnosed with postpartum hemorrhage, of the 19 respondents who had anemia there 15 respondents (4.7\%) were diagnosed with postpartum hemorrhage, while out of 305 respondents who did not experience anemia, 72 respondents (22.2\%) were diagnosed with postpartum bleeding. The conclusion of this study is that there is a significant relationship between labor, macrosomia and anemia with the incidence of postpartum hemorrhage.

\section{Keywords : Postpartum bleeding, old parturition, macrosomia,} anemia

\section{PENDAHULUAN}

Menurut data World Health Organization (WHO). Fakta menunjukkan lebih dari 350.000 di seluruh dunia meninggal setiap tahun akibat komplikasi kehamilan dan persalinan (Depkes, 2015). AKI di Indonesia juga masih tergolong tinggi jika dibandingkan dengan negara-negara Asia Tenggara, yaitu menempati urutan ke delapan dari 18 negara, sebesar 240 per 100.000 $\mathrm{KH}$, disusul India (230 pe $100.000 \mathrm{KH}$ ), Bhutan (200 per $100.000 \mathrm{KH}$ ), dan Filipina sebesar 94 per 100.000 KH (Kemenkes RI, 2012). Data World Health Organization (2018) menunjukan bahwa 25.000 dari kematian maternal disebabkan oleh perdarahan pasca persalinan dan diperkirakan 100.000 kematian maternal setiap tahunnya. Di berbagai Negara paling sedikit seperempat dari seluruh kematian ibu disebabkan oleh perdarahan, proposinya berkisar antara kurang dari 10-60\% (WHO, 2018).

Sustainable Development Goal (SDG's) merupakan sebuah dokumen yang akan menjadi acuan dalam kerangka pembangunan dan perundingan negara-negara didunia, salah satu indikator pencapaian SDG's adalah pada tahun 2030 terjadi penurunan rasio kematian ibu yang kurang dari 70 per 100.000 kelahiran hidup dan pada tahun 2030 mengakhiri dan mencegah kematian bayi dan balita (Wita solama, 2019).

Di Indonesia diperkirakan ada 14 juta kasus perdarahan dalam kehamilan.Setiap tahunnya paling sedikit 128.000 perempuan mengalami perdarahan sampai meninggal. Perdarahan pasca persalinan terutama perdarahan pasca persalinan primer merupakan perdarahan yang paling banyak menyebabkan kematian ibu. Perdarahan pasca persalinan primer yaitu perdarahan pasca persalinan yang terjadi dalam
24 jam pertama kelahiran (Masyuni, 2010 dalam Psiari, 2017).

Berdasarkan Profil Kesehatan Indonesia pada tahun 2017 terdapat empat penyebab kematian ibu terbesar yaitu diantaranya perdarahan 41.200 kasus, hipertensi dalam kehamilan 32.300 kasus, infeksi 8.230 kasus dan penyakit lainya yaitu penyebab kematian ibu tidak langsung seperti kondisi penyakit kanker, ginjal, jantung atau penyakit lain yang diderita ibu sebesar 18.270 kasus dari 100.000 kematian maternal (Kemenkes RI, 2017).

Perdarahan pasca persalinan adalah perdarahan atau hilangnya darah sebanyak lebih dari $500 \mathrm{ml}$ yang terjadi setelah anak lahir baik sebelum, selama, atau sesudah kelahiran plasenta. Kondisi dalam persalinan menyebabkan kesulitan untuk menentukan jumlah perdarahan yang terjadi karena tercampur dengan air ketuban dan serapan pakaian atau kain alas tidur (Prawirohardjo, 2016). Perdarahan pasca persalinan dapat terjadi pada kelahiran dengan makrosomia, hal ini disebabkan karena besarnya janin menyebabkan terjadi regangan pada uterus mulai sejak kehamilan sampai persalinan. Sehingga, menyebabkan kelelahan miometrium dan terganggunya kontraksi uterus setelah melahirkan dan pada persalinan normal bayi dengan makrosomia bisa menyebabkan ruptur perineum yang dapat meyebabkan terjadinya perdarahan pascapersalinan(Prawirohardjo, 2016)

Faktor penyebab perdarahan pasca persalinan antara lain : ibu hamil tidak pernah memeriksakan kehamilannya, memeriksakan kehamilan tetapi tidak teratur, atonia uteri retensio plasenta, ruptur uteri, inversio uteri, trauma jalan lahir dan gangguan sistem pembekuan darah, faktor predisposisi yang harus dipertimbangkan adalah usia ibu, riwayat perdarahan pasca persalinan sebelumnya, 
grandemultipara, perdarahan antepartum, dan partus lama (Mansjoer, 2015).

Menurut hasil penelitian Psiari Kusuma (2017) tentang factor - faktor yang mempengaruhi terjadinya perdarahan pasca persalinan, dari 71 responden terdapat hasil $\mathrm{Uji}$ statistic Chi-Square didapatkan $p$-value $=0,000$ untuk partus lama artinya ada hubungan bermakna antara partus lama dengan kejadian perdarahan pasca persalinan (Psiari, 2017). Partus lama dapat menimbulkan efek terhadap ibu maupun janin. Pada partus lama terdapat kenaikan insidensi atonia uteri, laserasi, perdarahan, infeksi, kelelahan ibu dan syok. Partus lama dapat menyebabkan terjadinya inersia uteri karena kelelahan pada otot - otot uterus sehingga rahim berkontraksi lemah setelah bayi lahir dan dapat menyebabkan terjadinya perdarahan pasca persalinan (Varney, 2007 dalam Psiari, 2017).

Wanita yang mengalami anemia dalam persalinan dengan kadar hemoglobin $<11 \mathrm{gr} / \mathrm{dl}$ akan dengan cepat terganggu kondisinya bila terjadi kehilangan darah meskipun hanya sedikit. Anemia dihubungkan dengan kelemahan yang dapat dianggap sebagai penyebab langsung perdarahan pasca persalinan(Yekti, 2017).

Menurut hasil penelitian Fitria (2015) tentang hubungan partus lama, riwayat perdarahan postpartum dan berat bayi lahir besar (makrosomia) dengan kejadian perdarahan postpartum di RSUD Kanjuruhan Kepanjen Malang Tahun 2015, dari 71 responden terdapat hasil Uji statistic Chi-Square didapatkan p-value $=0,001$ untuk makrosomia artinya ada hubungan bermakna antara makrosomia dengan kejadian perdarahan pasca persalinan (Fitria, 2015).

Berdasarkan data yang diperoleh dari Rumah Sakit Umum Daerah Kota Prabumulih, diketahui bahwa pada tahun 2017 terdapat 127orang $(9,17 \%)$ dengan pendarahan pasca persalinan dari 1385 ibu bersalin, tahun 2018 terdapat 150 orang $(9,24 \%)$ dengan pendarahan pasca persalinan dari 1622 ibu bersalin, tahun 2019 terdapat 168orang $(9,81 \%)$ dengan pendarahan pasca persalinan dari 1712 ibu bersalin (Rekam Medik RSUD Kota Prabumulih, 2019).

Berdasarkan data diatas maka penulis tertarik untuk melakukan penelitian dengan judul " Faktor-faktor yang mempengaruhi terjadinya perdarahan pasca persalinan di Rumah Sakit Umum Daerah Tahun 2019”.

\section{METODE PENELITIAN}

Jenis penelitian ini menggunakan metode survey analitik dengan pendekatan Cross Sectional dimana variabel independent dan variabel dependent dikumpulkan dalam waktu yang bersamaan.

Populasi penelitian ini adalah seluruh ibu bersalin diruang kebidanan Rumah Sakit Umum Daerah Kota Prabumulih dari tanggal 1 Januari sampai dengan 31 Desember 2019 yaitu sebanyak 1712 orang. Sampel dalam penelitian ini menggunakan teknik Random Sampling, maka sampel yang digunakan pada penelitian ini sebanyak 324 orang.

Dalam penelitian data yang digunakan data sekunder. Data sekunder adalah data yang didapat dari suatu lembaga instansi. Dalam penelitian ini data sekunder diperoleh dari data rekam medik Rumah Sakit Umum Daerah Kota Prabumulih dan penelusuran buku maupun internet mengenai kejadian perdarahan pasca persalinan.

Analisis data yang digunakan adalah analisis univariat dan analisis bivariat. Data diatas dianalisis menggunakan uji statistik chisquare dengan batas kemaknaan $\alpha=0.05$ dimana analisis data dilakukan dengan sistem komputerisasi. Sehingga didapat nilai $\rho$ value untuk melihat tingkat kemaknaan.

\section{HASIL PENELITIAN}

Hasil-hasil penelitian dapat dilihat pada tabeltabel yang disajikan.:

Tabel 1 Hubungan antara partus lama dengan kejadian perdarahan pasca persalinandi RSUD Kota Prabumulih tahun 2019

\begin{tabular}{|c|c|c|c|c|c|c|c|}
\hline \multirow{3}{*}{$\begin{array}{c}\text { Partus } \\
\text { lama }\end{array}$} & \multicolumn{6}{|c|}{ Kejadian perdarahan pasca persalinan } & \multirow{3}{*}{$\begin{array}{c}P \\
\text { value }\end{array}$} \\
\hline & \multicolumn{2}{|c|}{ Ya } & \multicolumn{2}{|c|}{ Tidak } & \multicolumn{2}{|c|}{ Jumlah } & \\
\hline & $\mathbf{N}$ & $\%$ & $\mathbf{n}$ & $\%$ & $\mathbf{N}$ & $\%$ & \\
\hline Ya & 11 & 3,4 & 3 & 9 & 14 & 4,3 & \multirow{3}{*}{0,000} \\
\hline Tidak & 76 & 23,5 & 234 & 72,2 & 310 & 95,7 & \\
\hline Jumlah & 87 & 26,9 & 237 & 73,1 & 324 & 100 & \\
\hline
\end{tabular}

Dari tabel diatas dapat dilihat bahwa dari 324 responden terdapat 14 responden yang mengalami partus lama, dimana 11 responden $(3,4 \%)$ didiagnosa perdarahan pasca persalinan dan 3 responden (9\%) yang tidak didiagnosa perdarahan pasca persalinan sedangkan dari 310 responden yang tidak mengalami partus lama terdapat 76 responden $(23,5 \%)$ didiagnosa perdarahan pasca persalinan dan 234 responden $(72,2 \%)$ tidak didiagnosa perdarahan pasca persalinan. Hasil Uji statistic Chi-Square 
Jurnal Kebidanan :Jurnal Medical Science Ilmu Kesehatan Akademi Kebidanan Budi Mulia Palembang Volume.10 No.2, Desember 2020

didapatkan $p$-value $=0,000$ artinya partus lama dengan kejadian perdarahan pasca persalinanada hubungan yang bermakna, sehingga hipotesis yang menyatakan ada hubungan yang bermakna antara partus lama dengan kejadian perdarahan pasca persalinan terbukti secara statistik.

\section{Tabel 2 Hubungan antara Makrosomia dengan kejadian perdarahan pasca persalinan di RSUD Kota Prabumulih tahun 2019}

\begin{tabular}{cccccccc}
\hline \multirow{2}{*}{ Makrosomia } & \multicolumn{6}{c}{ Kejadian perdarahan pasca } & \multirow{2}{*}{$\begin{array}{c}\boldsymbol{P} \\
\end{array}$} \\
\cline { 2 - 7 } & \multicolumn{4}{c}{ Ya } & \multicolumn{6}{c}{ Tidak } & Jumlah & value \\
\cline { 2 - 7 } & $\mathbf{n}$ & $\mathbf{\%}$ & $\mathbf{n}$ & $\mathbf{\%}$ & $\mathbf{N}$ & $\mathbf{\%}$ & \\
\hline Ya & 19 & 5,9 & 8 & 2,4 & 27 & 8,3 & \\
\hline Tidak & 68 & 21 & 229 & 70,7 & 297 & 91,7 & 0,000 \\
\hline Jumlah & $\mathbf{8 7}$ & $\mathbf{2 6 , 9}$ & $\mathbf{2 3 7}$ & $\mathbf{7 3 , 1}$ & $\mathbf{3 2 4}$ & $\mathbf{1 0 0}$ & \\
\hline
\end{tabular}

Dari tabel diatas dapat dilihat bahwa dari 324 responden terdapat 27responden yang memiliki janin dengan makrosomia, dimana 19 responden $(5,9 \%)$ yang didiagnosa perdarahan pasca persalinan dan 8 responden $(2,4 \%)$ tidak didiagnosa perdarahan pasca persalinan sedangkan dari 297responden yang tidak memiliki janin dengan makrosomia terdapat 68responden $(21 \%)$ yang didiagnosa perdarahan pasca persalinan dan 229 responden $(70,7 \%)$ yang tidak didiagnosa perdarahan pasca persalinan.

Hasil Uji statistic Chi-Square didapatkan p-value $=0,000$ artinya antara makrosomia dengan kejadian perdarahan pasca persalinan ada hubungan yang bermakna, sehingga hipotesis yang menyatakan ada hubungan yang bermakna antara makrosomia dengan kejadian perdarahan pasca persalinanterbukti secara statistik.

Hasil penelitian ini sejalan dengan hasil penelitian yang dilakukan Fitria (2015) tentang hubungan partus lama, riwayat perdarahan postpartum dan berat bayi lahir besar (makrosomia) dengan kejadian perdarahan postpartum di RSUD Kanjuruhan Kepanjen Malang Tahun 2015, dari 71 responden terdapat hasil Uji statistic Chi-Square didapatkan p-value $=0,001$ untuk makrosomia artinya ada hubungan bermakna antara makrosomia dengan kejadian perdarahan pasca persalinan (Fitria, 2015).

\section{Tabel 3 Hubungan antara Anemia dengan kejadian perdarahan pasca persalinan di RSUD Kota Prabumulih tahun 2019}

\begin{tabular}{cccccccc}
\hline \multirow{2}{*}{ Anemia } & \multicolumn{6}{c}{ Kejadian perdarahan pasca } & \multirow{2}{*}{$\boldsymbol{P}$} \\
& \multicolumn{4}{c}{ Ya } & \multicolumn{4}{c}{ Tidak } & \multicolumn{2}{c}{ Jumlah } & value \\
\cline { 2 - 6 } & $\mathbf{n}$ & $\mathbf{\%}$ & $\mathbf{n}$ & $\mathbf{\%}$ & $\mathbf{N}$ & $\mathbf{\%}$ & \\
\hline Ya & 15 & 4,7 & 4 & 1,2 & 19 & 5,9 & \\
\hline Tidak & 72 & 22,2 & 233 & 71,9 & 305 & 94,1 & 0,000 \\
\hline Jumlah & $\mathbf{8 7}$ & $\mathbf{2 6 , 9}$ & $\mathbf{2 3 7}$ & $\mathbf{7 3 , 1}$ & $\mathbf{3 2 4}$ & $\mathbf{1 0 0}$ & \\
\hline
\end{tabular}

Dari tabel diatas dapat dilihat bahwa dari 324 responden terdapat 19responden yang mengalami anemia, dimana 15 responden $(4,7 \%)$ yang didiagnosa perdarahan pasca persalinan dan 4 responden $(1,2 \%)$ tidak didiagnosa perdarahan pasca persalinan sedangkan dari 305responden yang tidak mengalami anemiaterdapat 72responden $(22,2 \%)$ yang didiagnosa perdarahan pasca persalinan dan 233 responden $(71,9 \%)$ yang tidak didiagnosa perdarahan pasca persalinan.

Hasil Uji statistic Chi-Square didapatkan $p$-value $=0,000$ artinya antara anemia dengan kejadian perdarahan pasca persalinan ada hubungan yang bermakna, sehingga hipotesis yang menyatakan ada hubungan yang bermakna antara anemia dengan kejadian perdarahan pasca persalinanterbukti secara statistik.

Hasil penelitian ini sejalan dengan hasil penelitian yang dilakukan Yekti (2017) tentang faktor-faktor yang mempengaruhi kejadian perdarahan pasca persalinan di RSUD Panembahan Senopati Kabupaten Bantul, dengan 80 responden terdapat $50 \%$ responden mengalami perdarahan dan terdapat hasil Uji statistic ChiSquare didapatkan $p$-value $=0,016$ yang berarti bahwa ada hubungan yang bermakna antara anemia dengan kejadian perdarahan pasca persalinan.

\section{PEMBAHASAN}

1. Hubungan Partus Lama dengan kejadian perdarahan pasca persalinan di RSUD Kota Prabumulih Tahun 2019

Hasil Uji statistic Chi-Square didapatkanpvalue $=0,000$ artinya partus lama dengan kejadian perdarahan pasca persalinanada hubungan yang bermakna, sehingga hipotesis yang menyatakan ada hubungan yang bermakna antara partus lama dengan kejadian perdarahan pasca persalinan terbukti secara statistik.

Hasil penelitian ini sejalan dengan hasil penelitian Psiari Kusuma (2017) tentang faktorfaktor yang mempengaruhi terjadinya perdarahan pasca persalinan, dari 71 responden terdapat hasil Uji statistic Chi-Square didapatkan p-value = 0,000 dan 0,001 untuk partus lama dan riwayat 
seksio sesarea artinya ada hubungan bermakna antara partus lama dan riwayat seksio sesarea dengan kejadian perdarahan pasca persalinan (Psiari, 2017).

Partus lama adalah persalinan yang berlangsung lebih dari 24 jam pada primi dan lebih dari 18 jam pada multi. Partus lama baik fase aktif memanjang maupun kala II memanjang menimbulkan efek terhadap ibu maupun janin.Terdapat kenaikan terhadap insidensi atonia uteri, laserasi, perdarahan, infeksi, kelelahan ibu dan syok.Partus lama dapat menyebabkan terjadinya inersia uteri karena kelelahan pada otot - otot uterus sehingga rahim berkontraksi lemah setelah bayi lahir dan dapat menyebabkan terjadinya perdarahan pasca persalinan (Varney, 2007 dalam Psiari, 2017).

Penelitian oleh Dina, Seweng, dan Nyorong (2013) menyatakan bahwa partus lama merupakan faktor resiko perdarahan postpartum, dimana besar resikonya adalah 3,5 yang artinya ibu yang mengalami partus lama mempunyai resiko 3,5 kali lebih besar untuk mengalami perdarahan post partum dibandingkan ibu yang tidak mengalami partus lama.

\section{Hubungan Makrosomia dengan kejadian perdarahan pasca persalinan di RSUD Kota Prabumulih Tahun 2019}

Hasil Uji statistic Chi-Squaredidapatkan $p$ value $=0,000$ artinya antara makrosomia dengan kejadian perdarahan pasca persalinan ada hubungan yang bermakna, sehingga hipotesis yang menyatakan ada hubungan yang bermakna antara makrosomia dengan kejadian perdarahan pasca persalinanterbukti secara statistik.

Hasil penelitian ini sejalan dengan hasil penelitian Fitria (2015) tentang hubungan partus lama, riwayat perdarahan postpartum dan berat bayi lahir besar (makrosomia) dengan kejadian perdarahan postpartum di RSUD Kanjuruhan Kepanjen Malang Tahun 2015, dari 71 responden terdapat hasil Uji statistic Chi-Square didapatkan $p$-value $=0,001$ untuk makrosomia artinya ada hubungan bermakna antara makrosomia dengan kejadian perdarahan pasca persalinan (Fitria, 2015).

Berat bayi lahir yang lebih dari normal atau yang dalam penelitian ini disebut makrosomia dapat menyebabkan perdarahan postpartum karena uterus meregang berlebihan dan mengakibatkan lemahnya kontraksi sehingga dapat terjadi perdarahan postpartum.Kondisi ini karena uterus mengalami overdistensi sehingga mengalami hipotoni atau atonia uteri setelah persalinan.Adapun beberapa keadaan overdistensi uterus yang juga dapat menyebabkan atonia uteri yaitu kehamilan ganda dan hidramnion (Cuningham, 2005 dalam Fitria, 2015).

\section{Hubungan Anemia dengan kejadian perdarahan pasca persalinan di RSUD Kota Prabumulih Tahun 2019}

Hasil Uji statistic Chi-Squaredidapatkan $p$ value $=0,000$ artinya antara anemia dengan kejadian perdarahan pasca persalinan ada hubungan yang bermakna, sehingga hipotesis yang menyatakan ada hubungan yang bermakna antara anemia dengan kejadian perdarahan pasca persalinanterbukti secara statistik.

Hasil penelitian ini sejalan dengan hasil penelitian yang dilakukan Yekti (2017) tentang faktor-faktor yang mempengaruhi kejadian perdarahan pasca persalinan di RSUD Panembahan Senopati Kabupaten Bantul, dengan 80 responden terdapat $50 \%$ responden mengalami perdarahan dan terdapat hasil Uji statistic ChiSquare didapatkan $p$-value $=0,016$ yang berarti bahwa ada hubungan yang bermakna antara anemia dengan kejadian perdarahan pasca persalinan.

Anemia adalah suatu keadaan yang ditandai dengan penurunan nilai hemoglobin di bawah nilai normal, ibu hamil dikatakan anemia jika kadar hemoglobin kurang dari $11 \mathrm{~g} / \mathrm{dL}$. Kekurangan hemoglobin dalam darah dapat menyebabkan komplikasi lebih serius bagi ibu baik dalam kehamilan, persalinan, dan nifas (Manuaba, 2015).

Wanita yang mengalami anemia dalam persalinan dengan kadar hemoglobin <11gr/dl akan dengan cepat terganggu kondisinya bila terjadi kehilangan darah meskipun hanya sedikit. Anemia dihubungkan dengan kelemahan yang dapat dianggap sebagai penyebab langsung perdarahan postpartum (Yekti, 2017).

\section{KESIMPULAN}

Dari hasil penelitian yang dilakukan di Rumah Sakit Umum Kota Prabumulih tentang faktor-faktor yang mempengaruhi terjadinya perdarahan pasca persalinan di Rumah Sakit Umum Daerah Tahun 2019, maka peneliti menarik beberapa kesimpulan yang berkaitan dengan variabel yang diteliti dengan jumlah responden 324 orang yaitu:

Ada hubungan antara partus lama dengan kejadian perdarahan pasca persalinan di RSUD kota Prabumulih tahun 2019 dengan Chi-Square didapatkan $p$-value $=0,000 \leq \alpha(0,05)$. Ada hubungan antara makrosomia dengan kejadian perdarahan pasca persalinan di RSUD Kota 
Jurnal Kebidanan :Jurnal Medical Science Ilmu Kesehatan Akademi Kebidanan Budi Mulia Palembang Volume.10 No.2, Desember 2020

Prabumulih tahun 2019 dengan Chi square didapatkan $p$ value $=0,000 \leq \alpha(0,05$. Ada hubungan antara anemia dengan kejadian perdarahan pasca persalinan di RSUD Kota Prabumulih tahun 2019 dengan Chi square didapatkan $p$ value $=0,000 \leq \alpha(0,05)$.

\section{DAFTAR PUSTAKA}

Ayulia, fardilasari.

2015. Sustainable Development Goal (SDG's). (http://www.ayulia. blogspot. com diakses 10 Februari 2020).

Depkes RI. (2012). Profil Kesehatan Indonesia, Kementerian Kesehatan RI, Jakarta (http://www.Depkes RI blogspot. com diakses 12 Februari 2020).

Depkes RI. (2015). Profil Kesehatan Indonesia, Kementerian Kesehatan RI, Jakarta (http://www.Depkes RI blogspot. com diakses 12 Februari 2020).

Dina. 2013. Hubungan partus lama dan anemia dengan kejadian perdarahan postpartum diRSUD Ambarawa (http://www.Dina blogspot.com diakses 19 Februari 2020).

Fitria.2015. Hubungan partus lama, riwayat perdarahan postpartum dan berat bayi lahir besar dengan kejadian perdarahan postpartum di RSUD Kanjuruhan Kepanjen Malang Tahun 2013. (http://www.Fitria blogspot. com diakses 15 Februari 2020).

Kementerian Kesehatan RI. (2014). Profil Kesehatan Indonesia 2014. Jakarta. (http://www.Kemenkes RI blogspot. com diakses 12 Februari 2020).

Manuaba, I, B, G. Bagus Gede. 2010. Ilmu Kebidanan, Penyakit Kandungan dan KB, Jakarta, ECG.

Mansjoer. 2011. Kapita Selekta Kedokteran. Edisi ketiga. Jakarta, Media Aesculapius.

Masyuni, Sri. 2010. Analisis faktor-faktor yang berhubungan dengan perdarahan post partumprimer di RSUD Rokan Hulu.http://www.Masyuni. org. id diakses 20 Februari 2020

Notoatmodjo,S. 2010. Ilmu Kesehatan Masyarakat. Jakarta. Rineka Cipta
Prawirohardjo, Sarwono. 2010. Pelayanan Kesehatan Maternal dan Neonatal. Edisi Pertama. Jakarta. YBP-SP.

Priyanto. 2010. Metode penelitian. Yogyakarta. Gramedia.

Psiari Kusuma. 2017.faktor- faktor yang mempengaruhi terjadinya perdarahan pasca persalinan RSUD $d r$. A. Dadi Tjokrodipo Kota Bandar Lampung(http://www.Psiari kusuma blogspot.com. di akses18 Februari 2020)

Rochjati, Poedji. 2003. Skrining Antenatal Pada Ibu Hamil. Airlangga University Press, Surabaya. (http://www.Rochjati. blogspot.com diakses 19 Februari 2020). 
